\title{
Double orifice mitral valve visualized on echocardiography and MRI
}

\author{
C. B. Marcu • A. M. Beek • C. N. Ionescu • \\ A. C. Van Rossum
}

Published online: 13 May 2011

(C) The Author(s) 2011. This article is published with open access at Springerlink.com

A 21-year-old, previously healthy, female presented with complaints of palpitations. The physical examination, ECG and a 24-hour Holter investigation were unremarkable.

A transthoracic echocardiogram demonstrated a double orifice mitral valve (DOMV) (Fig. 1). Cardiac magnetic resonance imaging was performed in order to exclude other congenital heart problems (Fig. 2). There was no evidence of mitral valve stenosis, regurgitation or other cardiac morphological abnormalities.
First described in 1876 by Greenfield [1], DOMV is an uncommon anomaly which, as its name indicates, has a single mitral annulus and opens into the left ventricle through two orifices. Depending on the relative size and location of the two orifices, DOMV can be classified into an eccentric type (found in $85 \%$ of cases) and a central or bridge type (as in our patient's case) [2]. Mitral stenosis or regurgitation and other congenital malformations such as atrioventricular or ventricular septal defects may be associated with DOMV [3, 4].

Fig. 1 Transthoracic echocardiogram. a Apical 4-chamber view with 'seagull' appearance of the mitral valve (white arrow); $\mathbf{b}$ Parasternal short axis with bridge of tissue (dark arrow) dividing the mitral valve into two equal orifices
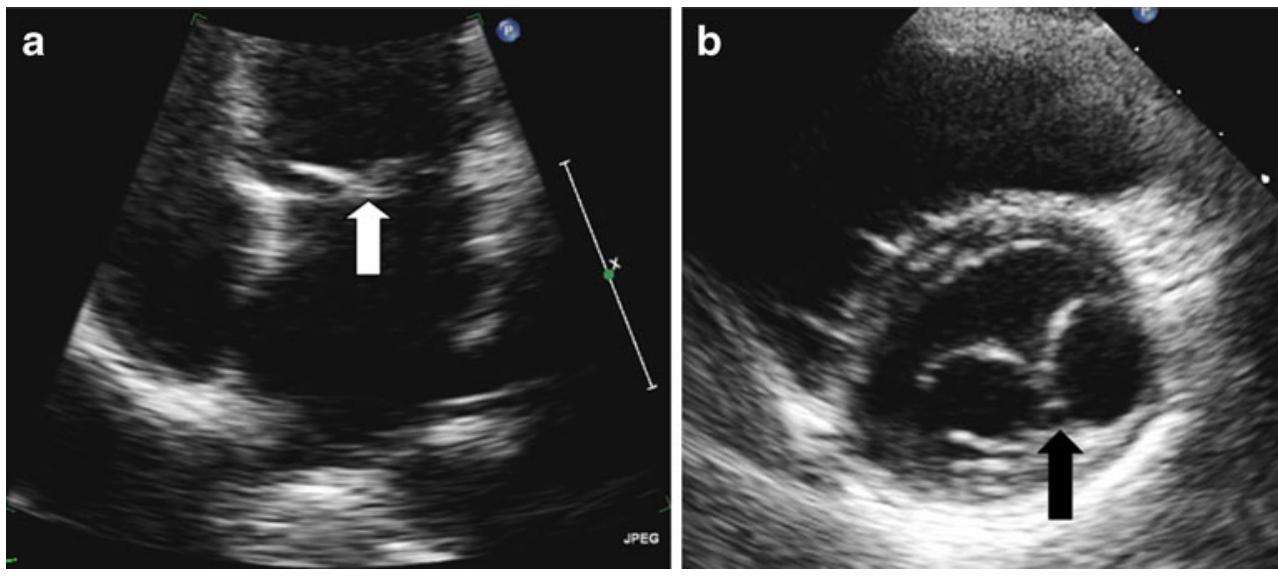

C. B. Marcu $(\bowtie) \cdot$ A. M. Beek $\cdot$ A. C. Van Rossum

Department of Cardiology, VU University Medical Centre,

de Boelelaan 1117 ,

1081 HV Amsterdam, the Netherlands

e-mail: bogdan.marcu@vumc.nl

C. N. Ionescu

Hospital of Saint Raphael,

New Haven, CT, USA 
Fig. 2 Cardiac MRI. a

Short-axis mitral valve gradient echo cine MRI image demonstrating the two orifices $\mathbf{b}$ )

Corresponding phase contrast velocity encoded MRI

(maximum velocity $100 \mathrm{~cm} / \mathrm{s}$ ) image demonstrating normal flow through the mitral valve
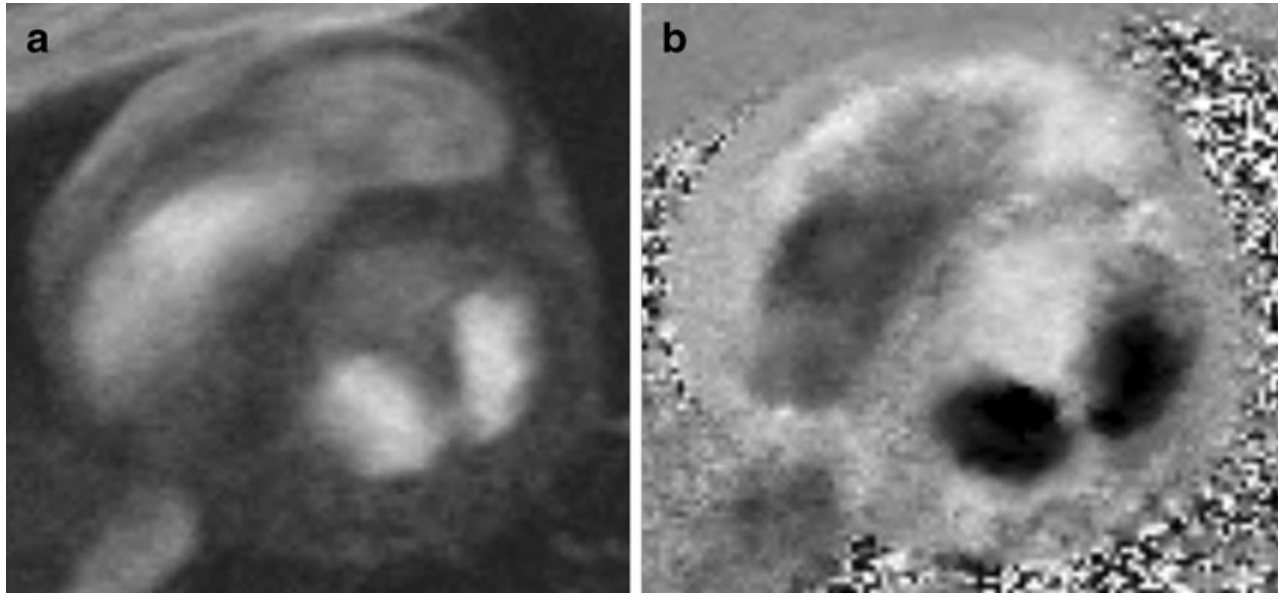

Open Access This article is distributed under the terms of the Creative Commons Attribution Noncommercial License which permits any noncommercial use, distribution, and reproduction in any medium, provided the original author(s) and source are credited.

\section{References}

1. Greenfield WS. Double mitral valve. Trans Pathol Soc. 1876;27:1289
2. Anwar AM, McGhie JS, Meijboom FJ, Ten Cate FJ. Double orifice mitral valve by real-time three-dimensional echocardiography. Eur J Echocardiogr. 2008;9(5):731-2.

3. Bano-Rodrigo A, Van Praagh S, Trowitzsch E, Van Praagh R. Double-orifice mitral valve: a study of 27 postmortem cases with developmental, diagnostic and surgical considerations. Am J Cardiol. 1988;61(1):152-60.

4. Das BB, Pauliks LB, Knudson OA, et al. Double-orifice mitral valve with intact atrioventricular septum: an echocardiographic study with anatomic and functional considerations. J Am Soc Echocardiogr. 2005;18(3):231-6. 